\title{
The Utilisation of Outer Texts in the Practical Lexicography of African Languages
}

Emmanuel Chabata, African Languages Research Institute (ALRI), University of Zimbabwe, Harare, Zimbabwe (emmanuelchabata@yahoo.com)

and

Dion Nkomo, Department of Afrikaans and Dutch, University of Stellenbosch, Stellenbosch; and Multilingualism Education Project, Centre for Higher Education Development, University of Cape Town, South Africa (deeouf@yahoo.co.uk)

\begin{abstract}
In this article, an analysis of the utilisation of outer texts in recently compiled dictionaries of African languages is presented. The analysis is undertaken in the context of an upsurge of the compilation of dictionaries in the African languages. It is undertaken with a view to do a qualitative evaluation of the many new dictionaries of African languages that have come on the market in recent years. The point of departure is that prior to the recent lexicographic developments, the then available dictionaries were compiled in the context of the limited role the African languages played. It has been found that most of those dictionaries are limited in scope, perspective and function and hence less effective now that the languages are being assigned a greater social role. The evaluation of outer texts in modern dictionaries is therefore a way of measuring the extent to which lexicographic practice in the African languages is applying theoretical developments to produce better dictionaries.
\end{abstract}

Keywords: LEXICOGRAPHY, LEXICOGRAPHIC PRACTICE, METALEXICOGRAPHY, DICTIONARIES, AFRICAN LANGUAGES, FRAME STRUCTURE, OUTER TEXTS, FRONT MATTER, BACK MATTER, MIDDLE MATTER, LEXICOGRAPHIC DATA

Opsomming: Die aanwending van buitetekste in die praktiese leksikografie van die Afrikatale. In hierdie artikel word 'n ontleding van die aanwending van buitetekste in onlangs saamgestelde woordeboeke van die Afrikatale aangebied. Die ontleding word gedoen in die konteks van ' $n$ oplewing in die samestelling van woordeboeke in die Afrikatale. Dit word onderneem met die oog daarop om 'n kwalitatiewe beoordeling van die baie nuwe woordeboeke van die Afrikatale te doen wat in die laaste jare op die mark gekom het. Die vertrekpunt is dat, voor die onlangse leksikografiese ontwikkelinge, die toe beskikbare woordeboeke saamgestel is binne die konteks van die beperkte rol wat die Afrikatale gespeel het. Daar is vasgestel dat die meeste van daardie woordeboeke beperk in omvang, dimensie en funksie en daarom minder doeltreffend is noudat ' $n$ groter maatskaplike rol aan die tale toegeken is. Die beoordeling van buitetekste in moderne woordeboeke is daarom 'n manier om die omvang te bepaal waartoe die leksikografiese praktyk in die Afrikatale teoretiese ontwikkelinge toepas om beter woordeboeke voort te bring. 
Sleutelwoorde: LEKSIKOGRAFIE, LEKSIKOGRAFIESE PRAKTYK, METALEKSIKOGRAFIE, WOORDEBOEKE, AFRIKATALE, RAAMSTRUKTUUR, BUITETEKSTE, VOORWERK, AGTERWERK, MIDDELWERK, LEKSIKOGRAFIESE DATA

\section{Introduction}

Zgusta (1991: 334) described the period of the 1970s as "the Golden Age of lexicography". Indeed, lexicography was experiencing what, at that time, had no precedent in its history. Not only were dictionaries being produced in great plenty, but lexicography was actually establishing itself as a fully-fledged discipline, with theoretical lexicography complementing lexicographic practice. While this was generally evident in other languages of the world, it was not the case with African languages where a few speech communities could only have access to very limited lexicographic products, limited in number, typology and quality. At that time, the available dictionaries were those produced in a pretheoretical environment, compiled mostly by non-linguists incompetent in the less researched African languages. The dictionaries were also produced in the context of the very limited role played by the African languages in the respective communities in which they are used.

For the African languages, the "Golden Age of lexicography" really began in the 1990s when more and new dictionaries began to be produced with a view to empowering the speech communities. It was also then that African linguists became more interested in theoretical lexicography, starting groundbreaking collaboration with international scholars in the field. The African Languages Lexical (ALLEX) Project, which led to the establishment of the African Languages Research Institute (ALRI), was established in 1992 as a collaborative research venture between the University of Zimbabwe and the Universities of Oslo and Gothenburg to produce, among other tools, mother tongue dictionaries in Shona and Ndebele (cf. Chabata 2007, 2008). As the decade ended, the establishment of National Lexicography Units (NLUs) in South Africa signalled a coordinated approach to lexicographic practice of which one target was to empower the multilingual South African nation, including the indigenous speech communities. Ever since then, lexicographic practice has been continuing in these and other African countries, with metalexicography also playing a guiding and supporting role, especially in the form of academic training and contributions in lexicographic journals such as Lexikos, always investigating and addressing lexicographic challenges through the application of lexicographic theories.

This article analyses the utilisation of outer texts in some of the modern dictionaries produced for the African languages. It is a qualitative effort to measure the extent to which the theories of frame structure and outer texts are reflected in the dictionaries. As has always been reiterated by scholars, lexicographic theory is necessary for enhancing lexicographic practice and dictionary use (cf. Gouws and Prinsloo 2005: 1; Tarp 2008: 11). This article investigates 
how the theoretical insights from dictionary structure studies have been applied to produce functional and user-friendly dictionaries, mainly focusing on the utilisation of outer texts.

\section{Lexicographic practice in African languages}

In order to fully appreciate the current lexicographic developments in African languages, it is important to bear in mind that several dictionaries were produced in these languages many years ago as part of missionaries' efforts to develop the languages so that they could be used for evangelism. These were complemented by the colonial governments' efforts of standardising and developing the languages, which were meant to educate the Africans so that they could easily be converted to European culture, which was anti-African. For example, Hartmann (1990) indicates that several African languages already had dictionaries at the turn of the last decade of the 20th century. In spite of the recent rise in lexicographic activities, the African languages have even up to now not adequately been provided for. For instance, Gouws (1996: 99) observes:

Although the South African languages have a comprehensive collection of dictionaries, it is not hard to detect imbalances between languages, types of dictionaries and lexicographic systems.

Writing specifically on Zimbabwean dictionaries that have been in existence for quite some time, Chabata (2007: 280) argues that they:

were either limited in scope or lacked the much needed focus towards the development and raising of the status of these (indigenous) languages. ... The dictionaries published were bilingual. Generally speaking, bilingual dictionaries are mainly meant for second-language learners. In the case of the Zimbabwean languages, the dictionaries were compiled for the use of the colonial authorities.

The reasons for this state of affairs are historical. The dictionaries were produced in line with the colonial language policies which allotted very limited roles for indigenous languages, mainly for education and evangelisation. That way, they may be characterised as externally-motivated lexicographic products because they were produced to serve the needs that were mainly determined by external members of the African language speech communities (Nkomo 2008: 10; Gouws 2005: 97; Awak 1990: 10; Busane 1990: 20). A good case in point is Weale's (1903) dictionary whose subtitle states clearly that it was "meant for the use of prospectors and farmers in MaShonaland". At that time, the native speakers of the indigenous languages in Zimbabwe were mainly labourers on the mines and farms owned by colonial settlers. However, another very important reason that needs to be acknowledged regarding the poor quality of most dictionaries compiled during the colonial era is that some metalexicographic advances applied in modern lexicography were yet to be 
made. Most dictionary compilers during the colonial era were missionaries, with some of them being linguists without lexicographic expertise and adequate linguistic competence in the indigenous languages.

With new language policies now set in place in post-colonial African states (even though the new policies have not been fully implemented), more research in the indigenous languages, lexicographic training and metalexicographic advances to support lexicographic practice, the production of dictionaries in the African languages is currently undertaken in a completely different environment. Not only should the communities be provided with more dictionaries of different types, but also with dictionaries of a higher functional value. The progress that lexicographic practice is now experiencing needs to satisfy both the quantitative evaluation which mainly focuses on the availability of dictionaries and their contents, and the qualitative evaluation which focuses on their functional success in terms of both adequacy and accessibility of lexicographic data. As long as the dictionaries that are produced become superior to their predecessors only in terms of contents and ideology, the intended users will find them difficult to use. Lexicographers would be merely compiling dictionaries which satisfy themselves instead of empowering the users. In the remainder of this article, the utilisation of outer texts in the recently produced African language dictionaries will be examined in order to determine the progress that African lexicography has made in his respect.

\section{Metalexicographic advances in the study of outer texts}

A linguistic bias which dominated lexicographic practice and scholarship until the final three decades of the twentieth century continued to hinder progress in the planning and utilisation of outer texts in dictionaries. This is not to suggest that dictionaries always consisted exclusively of word lists. They did contain outer texts which, however, were arbitrarily selected and barely utilised for optimal information transfer to the user. Quite often, the outer texts were regarded as appendages to the dictionaries, and rarely as dictionary components. The acknowledgement that the dictionary is a "big text" or a "text compound" (Gouws 2004: 69) consisting of various kinds of texts and subtexts resulted from conscious efforts of developing lexicographic theory. The first scholar to broaden the scope of lexicography in this regard was Wiegand through a quest to formulate a general theory of lexicography (see, for example, Wiegand 1984). Although he did not affirm the status of lexicography as an independent and fully-fledged discipline, he categorically disposed of the longheld view that it was simply part of linguistics or applied linguistics. Wiegand (1984: 13) argued:

Lexicography is not a branch of so-called applied linguistics. ... Lexicography is at all events, more than the application of linguistic theories and methods or the utilization of linguistic and philological findings. 
Lexicography is not a branch of lexicology, and lexicography is by no means theoretically determined by lexicology alone.

In a convincing way, he and other scholars (cf. Bergenholtz and Tarp 2003: 172) demonstrated that in some dictionary types, knowledge from other disciplines would be required in addition to or even exclusive of linguistics. The major difference is that Bergenholtz and Tarp have been uncompromisingly assertive of the status of lexicography as a fully-fledged discipline.

Of immediate relevance to this article is the notion of dictionary structure which Wiegand (1984: 17) identified from the outset as an important element of the general theory of lexicography. It became instructive that besides linguistic knowledge, lexicographers need special training and knowledge in order to produce dictionaries (cf. Gouws 2001). This knowledge would entail an ability to plan how dictionary contents could be distributed and arranged throughout a dictionary as it is now widely accepted that not only the availability of certain lexicographic data matters, but also their accessibility by means of dictionary structure (Svensén 2009: 8-9).

Attention was first given to the arrangement of lemmata as well as the presentation of other data categories by means of lexicographic conventions, indicating a clear furtherance of the long established word list bias (Gouws 2007: 77). These constituted what became known as the word list structure (Wiegand and Hausmann 1989: 333), within which the notions of macrostructure and microstructure had emerged (cf. Wiegand and Hausmann 1989: 328). The acknowledgement that not just the word list constitutes a dictionary introduced what was first called the textual book structure (Wiegand and Hausmann 1989: 330), and later became known as the frame structure (cf. Gouws 2002, 2004, 2007). In addition to the central list which is a compulsory text in any dictionary (Wiegand and Hausmann 1989: 331), the frame structure recognised the incorporation of the outer texts, consisting of the front matter, middle matter and back matter texts as part of the dictionary.

Having been originally conceived within Wiegand's general theory of lexicography, the notion of the frame structure or outer texts was initially applied in the description of certain existing dictionaries, leading certain scholars (e.g. Bergenholtz and Tarp 2003: 193) to argue that Wiegand's theory was contemplative and less useful in improving lexicographic practice. However, more research on dictionary structure and the frame structure in particular, advanced from being descriptive to being transformative. This may be discerned from the following comments of Gouws and Prinsloo (2005: 58):

When planning a new dictionary lexicographers have to realise that the functionality of the eventual products exceeds the boundaries of the central text. Both the front matter and the back matter can contain texts, which have a functional role in the presentation of the lexicographic data.

Such a transformative approach may be seen as motivated by the introduction of the notion of the data distribution structure by Bergenholtz, Tarp and Wie- 
gand (Gouws 2007: 81). Resultant metalexicographical advances gave way to analytical distinctions between integrated and non-integrated outer texts (Gouws 2004) and later function-adhering and non-function-adhering outer texts (Gouws 2007). Such distinctions may be helpful in the understanding of outer texts in existing dictionaries, as well as in their planning and utilisation in new dictionaries. These distinctions will not be reproduced here. Instead, the remaining sections of this article will focus on its specific contribution, which is to evaluate the extent to which progress has been made in African language lexicography regarding the use of outer texts. In so doing, these distinctions will be employed, where necessary, to support the hypothesis that African lexicographic practice has made significant progress in the utilisation of outer texts to facilitate optimum information transfer to the user.

\section{Outer texts in African language dictionaries}

An article by Nielsen (2009) reveals that very few metalexicographers understand the concept of outer texts or that a dictionary is a carrier of text types. In an analysis of dictionary reviews in Lexikos spanning over eighteen years, Nielsen (2009: 220) observes that:

many reviewers exclude outer texts from their evaluation. Those who do include outer texts treat these texts differently, ranging from mere acknowledgment of existence over a description to a critical evaluation.

This is unfortunate, given that dictionary reviews in academic journals such as Lexikos are supposedly written by writers with a better understanding of dictionaries and lexicography in general. However, it may be observed that in some cases, it is actually the dictionary compilers themselves who treat outer texts as mere appendages because of limited efforts to integrate these texts into the functions of the respective dictionaries. Many lexicographers continue to justify the underutilisation of outer texts by the argument, as indicated by Busane (1990: 28), that these texts are less frequently or rarely consulted by users. However, Gouws (2007: 81) reasons that it is normal that outer texts will be consulted less frequently compared to the central texts. For example, the user may need to read the guide to dictionary use once in order to use a specific dictionary for an entire lifetime. Thus lexicographers should continue using the outer texts and also devising more innovations for making them more useful and attractive to users. It is contended that this helps in improving the dictionary skills of the users and the general dictionary culture of language communities.

While there are still many dictionaries in the African languages that give little regard to the value of outer texts, the next subsections will focus on examples of dictionaries that demonstrate the progress already made in the utilisation of outer texts to improve dictionary functionality and user-friendliness. In the dictionaries in question, awareness of user needs and a young cul- 
ture of using dictionaries in African languages are furthering this progress on the part of lexicographers. The dictionaries of which the outer texts are considered are classified into general bilingual dictionaries, general monolingual dictionaries and specialised (LSP) dictionaries. Although these typological boundaries are not absolute, it will be observed that the importance of certain outer texts depends on the fact that different dictionary types do not only serve different functions, but that they may also serve similar functions quite differently. This has implications for the nature of the data provided by different dictionaries, their data distribution structures and the utilisation of outer texts.

\subsection{General bilingual dictionaries and their outer texts}

Although several bilingual dictionaries pairing African languages and major languages such as English and French have been in existence for many years, new bilingual dictionaries are being compiled. Their production is set to continue owing to the limitations of those produced in the past. The need to promote multilingualism in countries such as South Africa, for example, means that bi- and multilingual dictionaries have to be produced to support learners of both/all languages covered by a specific dictionary. For example, the Oxford Bilingual School Dictionary: Northern Sotho and English / Pukuntšu ya Polopedi ya Sekolo: Sesotho sa Leboa le Seisimane, henceforth the OBSDNSE/PPSLS, has been designed to enable "learners to read and write, and to hear and speak effectively and competently in their additional language" (De Schryver et al 2007: x). This subsection focuses on how this dictionary utilises outer texts to complement the main text in the realisation of these dictionary functions.

It could be for this reason that the compilers of the OBSDNSE/PPSLS have extensively employed outer texts as carriers of lexicographic data. Overall, the outer texts add up to 56 numbered pages: 12 pages for the front matter, 28 pages for the middle matter and 16 pages for the back matter. This way, the dictionary displays a "complete extension" whereby the main text is "complemented by both front and back matter texts (Gouws 2004: 69). The table of contents of the OBSDNSE/PPSLS presented below provides an overview of the frame structure of the dictionary.

The front matter provides an overview of the entire dictionary. In addition to the imprint and bibliographical pages, it comprises of three integrated outer texts, namely a table of contents, a text entitled "dictionary features" and an introduction. Firstly, the table of contents is directed at all the dictionary texts and subtexts. By simply looking at it, the user is able to see that besides the Northern Sotho-English A-Z and English-Northern Sotho A-Z sections, which are the main places of lexicographic treatment, there are other important texts namely the study and reference sections. As the main texts, the Northern Sotho-English A-Z and English-Northern Sotho A-Z sections on the contents page are indicated by a bolder font. It can be seen that the Northern SothoEnglish A-Z section which ends on page 254 is followed by the study section, 
which is entitled "Karolo ya go ithuta" in Sesotho sa Leboa and "Study section" in English. The reference section, "Karolo ya boikgakollo"/"Reference section", follows the English-Northern Sotho A-Z section after page 552.

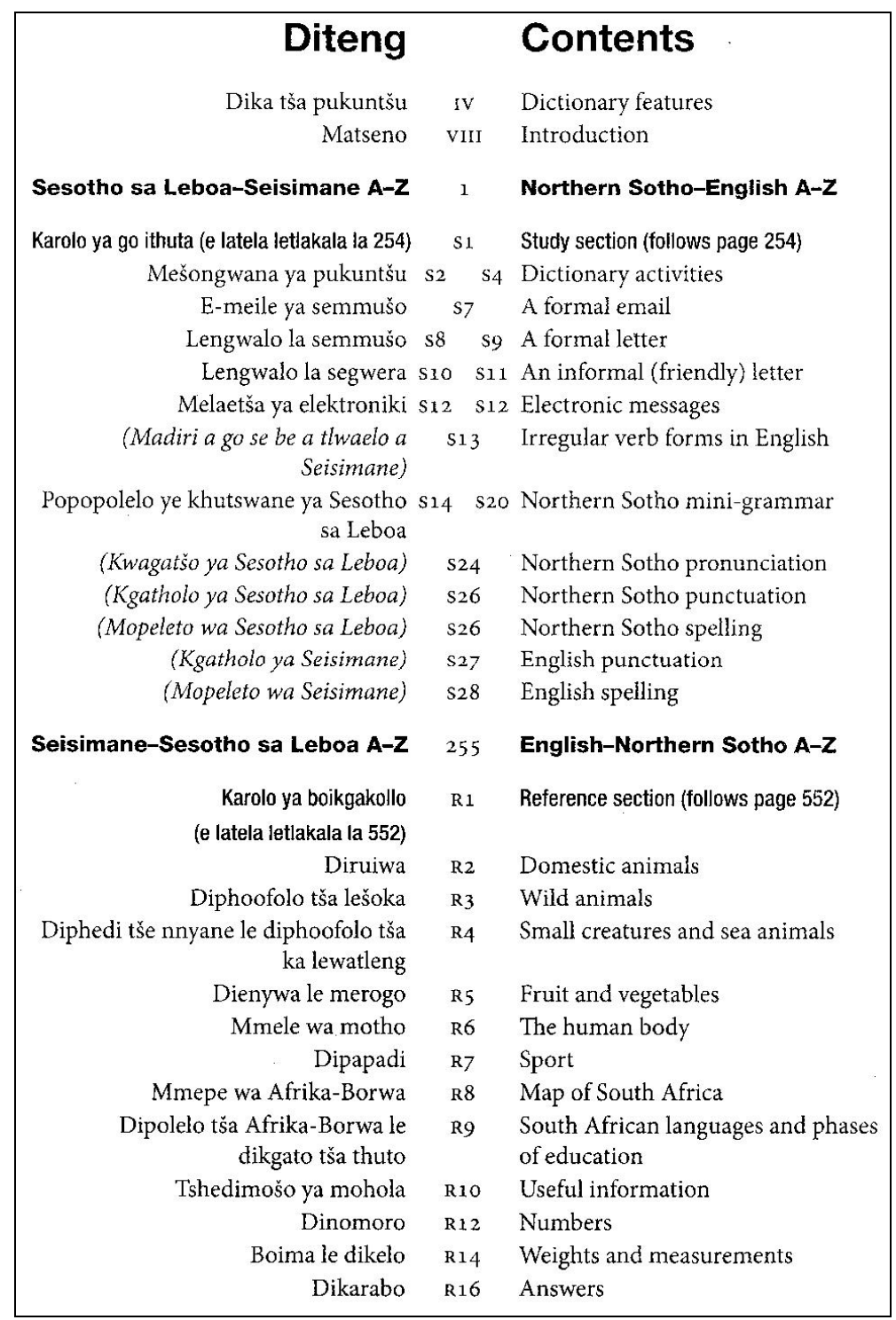

The OBSDNSE/PPSLS table of contents

Secondly, through the text titled "Dika tsa Pukuntšu"/"Dictionary features", the front matter explains in both Sesotho sa Leboa and English the relevance of the various data types included in the dictionary and the way they are represented. 
This is illustrated by means of labelled dictionary articles and entries from real dictionary pages. Finally, the introduction provides, among other information, a guide to dictionary use. Thus overall, the front matter provides the user with a concrete idea of the contents and the structure of the dictionary as well as the access routes of the dictionary. Doing this in both languages is consistent with the bilingualism endeavour of the dictionary.

As noted earlier, the study section is located between the Northern SothoEnglish $\mathrm{A}-\mathrm{Z}$ and the English-Northern Sotho A-Z sections of the dictionary. This location may be occupied by either the back matter of the Northern SothoEnglish $\mathrm{A}-\mathrm{Z}$ section or the front matter of the English-Northern Sotho A-Z section. However, it is neither the back matter nor the front matter of the respective A-Z sections, because it is directed at both. As back matter to the Northern Sotho-English A-Z section, it would be incomplete because the reference section is also directed at the same section. It is thus the middle matter of the entire dictionary. For example, the subtexts "Mesongwana ya Pukuntšu"/"Dictionary activities" are relevant for both the Northern Sotho-English $\mathrm{A}-\mathrm{Z}$ and the English-Northern Sotho A-Z sections as they seek to develop dictionary skills from native language speakers of both languages.

The middle matter of the OBSDNSE/PPSLS is a partially extended complex outer text in which a table of contents functions as a secondary outer text (cf. Gouws 2004: 70) by exposing and guiding the user to 12 subtexts. Its table of contents is extracted from the main table of contents presented above, falling between the Northern Sotho-English A-Z and the English-Northern Sotho A$\mathrm{Z}$ sections. Reproducing the relevant table of contents is convenient, because the user does not have to refer to the main table of contents once again. This can be viewed as user-friendly.

It may be seen that the provision of the middle matter advances the functions of the OBSDNSE/PPSLS which prevail in both the Northern Sotho-English $\mathrm{A}-\mathrm{Z}$ and the English-Northern Sotho A-Z sections. Whereas the subtexts given between S13 and S28 are indeed necessary to assist the learners of either language to produce appropriate oral and written texts, the subtexts ranging from S7 to S12 specifically support text production in communicative situations of writing formal emails, formal letters, informal (friendly) letters and electronic messages. Perhaps the only objection which could be raised regarding the middle matter would be the arrangement of its subtexts. Since learners also need information regarding spelling, punctuation and irregular inflection when writing formal emails and letters, the subtexts from S13 to S28 may have been more conveniently presented before those between S7 to S12.

The reference section forms the back matter of the OBSDNSE/PPSLS. Not only is it located after both the Northern Sotho-English A-Z and the EnglishNorthern Sotho A-Z sections, it is also relevant to both sections. Like the middle matter (study section), it is a partially extended complex outer text as it has its own table of contents, also extracted from the main table of contents of the dictionary ("Karolo ya boikgakollo"/"Reference section"). Its subtexts further 
advance the text production functions by indicating, for example, how names for the months of the year and days of the week are spelt in the two languages. However, texts such as the map of South Africa, South African languages and other useful information have a cognitive function which does not prevail in the main text. What is important is that the cognitive function is also important here, considering that the dictionary is meant for school learners.

\subsection{Monolingual dictionaries and their outer texts}

While bilingual lexicography in the indigenous African languages may be traced back to over a century ago, monolingual dictionaries only began to appear in the 1980s. The new dictionary type emerged against a background of the African languages playing a minimum social role owing to a lack of standardised orthographies, vocabulary and terminologies. Thus the monolingual dictionaries have had a standardisation role (cf. Hadebe 2006) and an overall language raising impact (Chimhundu 2005). Although the major contribution that general monolingual dictionaries are making in developing African languages are to be found in their main texts (A-Z sections), some compilers have utilised outer texts in a very complementary and productive manner. A quantitative and qualitative evaluation of the utilisation of outer texts in selected monolingual dictionaries in African languages is one indicator of the progress that African lexicography has made in recent years.

Writing on Isichazamazwi SesiNdebele, Hadebe (2006: 113) observed at the time that the dictionary had the largest front matter (47 pages) and back matter (18 pages) among Nguni language dictionaries. Important to note here is that Isichazamazwi SesiNdebele was largely shaped by the same socio-historical factors and guided by the same reason for compilation and the same general theoretical framework underlying the production of Duramazwi reChiShona and Duramazwi Guru reChiShona. These dictionaries and Isichazamazwi SesiNdebele share a lot, including the extensive utilisation of outer texts. Accordingly, it is befitting that before commenting on the utilisation of selected outer texts from the three general monolingual dictionaries, a sketch is presented of the frame structure of Duramazwi reChiShona, which was actually the first one to appear. When additional outer texts in the later dictionaries are discussed, they are seen as cumulative changes in the utilisation of outer texts which were made as the general compilation framework improved.

\begin{tabular}{|l|c|c|}
\hline Front matter (i-xxx) in English & Main Text (1-504) & Back matter \\
\hline Imprint & $\mathrm{Aa}-\mathrm{Zz}$ & \\
\hline List of editorial staff and participants & & \\
\hline ALRI \& Publisher addresses & & \\
\hline Preface & & \\
\hline Acknowledgements & & \\
\hline
\end{tabular}




\begin{tabular}{|l|l|l|}
\hline Request for users' comments & & \\
\hline Introduction & & \\
\hline Outline of Shona alphabet & & \\
\hline Shona noun class system & & \\
\hline Shona verbal extensions & & \\
\hline Lemma selection \& Defining formats & & \\
\hline The metalanguage list & & \\
\hline Guide to dictionary users & & \\
\hline
\end{tabular}

Table 1: The Frame structure of Duramazwi ReChiShona

The first column of Table 1 lists the front matter texts of Duramazwi reChiShona, the second column represents the main text while the empty third column indicates the lack of back matter. The dictionary has what Gouws (2004: 69) calls a partially extended frame structure, because all the outer texts complementing the main text are only located in the front matter. What is more vital are the constituent parts of the front matter and the way they complement the main text in the realisation of its functions.

Not all the front matter texts in Duramazwi reChiShona complement the main text. Some of those that do not complement the main text include the imprint, which provides biographical information that is useful for library cataloguing and indexing. There are also those texts included for other purposes than the realisation of the dictionary functions, such as the comprehensive list of editors and participants, acknowledgements, the editorial request for users' comments, ALRI's and the publisher's addresses as well as the preface. The editorial request page provides contact details through which dictionary users may direct their queries and convey their suggestions to the editorial staff to ensure that subsequent editions and future dictionaries are made more userfriendly. As these texts do not help in the realisation and execution of the dictionary's functions, they are therefore non-integrated and non-function-adhering outer texts.

The following are the front matter texts that complement the main text of Duramazwi reChiShona in fulfilling its functions:

- Mashoko okuvamba (Introduction)

- Mabhii anoshandiswa mubumbiro rokunyora ChiShona (An outline of the Shona alphabet)

- Zvidimbu zvemazwi nedudziro (Metalanguage list)

- Mipanda yamazita (An outline of the noun class system)

- Zvivanduriro zvezviito (An outline of verbal extentions)

- Nzira dzakashandiswa kusarudza nokutsanangura mazwi ari muduramazwi rino (Lemma selection and defining formats)

- Mazano okubatsira vanoshandisa duramazwi rino (Guide to dictionary use) 
The outer texts listed above may be divided into two categories according to the way they complement the main text of the dictionary. There are those texts that are venues of data which, just like the main text, may increase the user's knowledge about specific aspects of the Shona language. They include the outline of the Shona alphabet, the Shona noun class system and the Shona verbal extensions. For example, the outline of the Shona alphabet indicates the letters which constitute the Shona orthography and their pronunciation. This way, the outline provides the dictionary user with information regarding the orthography of standard Shona. This is especially important given the questions often raised regarding the gaps between written and spoken Shona whereby some sounds such as 'l', ' $q$ ' and 'th' realised in the spoken forms are not represented in writing. In this regard, the alphabetical outline complements the main text in the standardisation of the language since standard forms of words are preferred to or entered before dialectical forms. The noun class system shows the classes into which Shona nouns are classified. This summary in the front matter provides information that is useful in understanding the numbers forming part of every noun entry in the dictionary. The same applies to the table presenting the different types of verbal extensions, their forms and usage examples. This summary provides a guide to the formation of extended verbs as well as the meaning(s) that each verbal extension adds to the verb base. A closer look at the usage examples shows that the meanings provided are those predictable from the individual meanings of the verb base and the verbal extension. The table thus complements the main text, which does not contain extended verbs with predictable meanings. The assumption behind the exclusion of such verbs from the dictionary is that the summary in the front matter is enough in explaining how extended verbs are formed; hence their inclusion would be a form of redundancy. The outline of the Shona alphabet and other texts which provide useful information about the Shona language in the front matter of Duramazwi reChiShona are integrated function-adhering outer texts as they contain data which complements the lexicographic endeavours undertaken in the main text. However, some integrated function-adhering outer texts may serve functions which do not necessarily prevail in the main text.

The other group of front matter texts in Duramazwi reChiShona complement the main text by guiding users as quickly as possible to various kinds of dictionary data. They include the metalanguage list and all the other types of texts detailing lemma selection procedures, defining formats and other conventions used in the dictionary. These texts, called integrated non-functionadhering outer texts, facilitate the dictionary consultation procedure so that the user finds the relevant assistance.

The utilisation of outer texts in Isichazamazwi SesiNdebele and Duramazwi Guru reChiShona which were published five years after Duramazwi reChiShona display a remarkable improvement. Not only do these dictionaries utilise fully extended frame structures whereby back matter texts are also included, but more texts complementing the main texts in the realisation of both communi- 
cative and cognitive functions are also incorporated. Isichazamazwi SesiNdebele contains the following back matter texts:

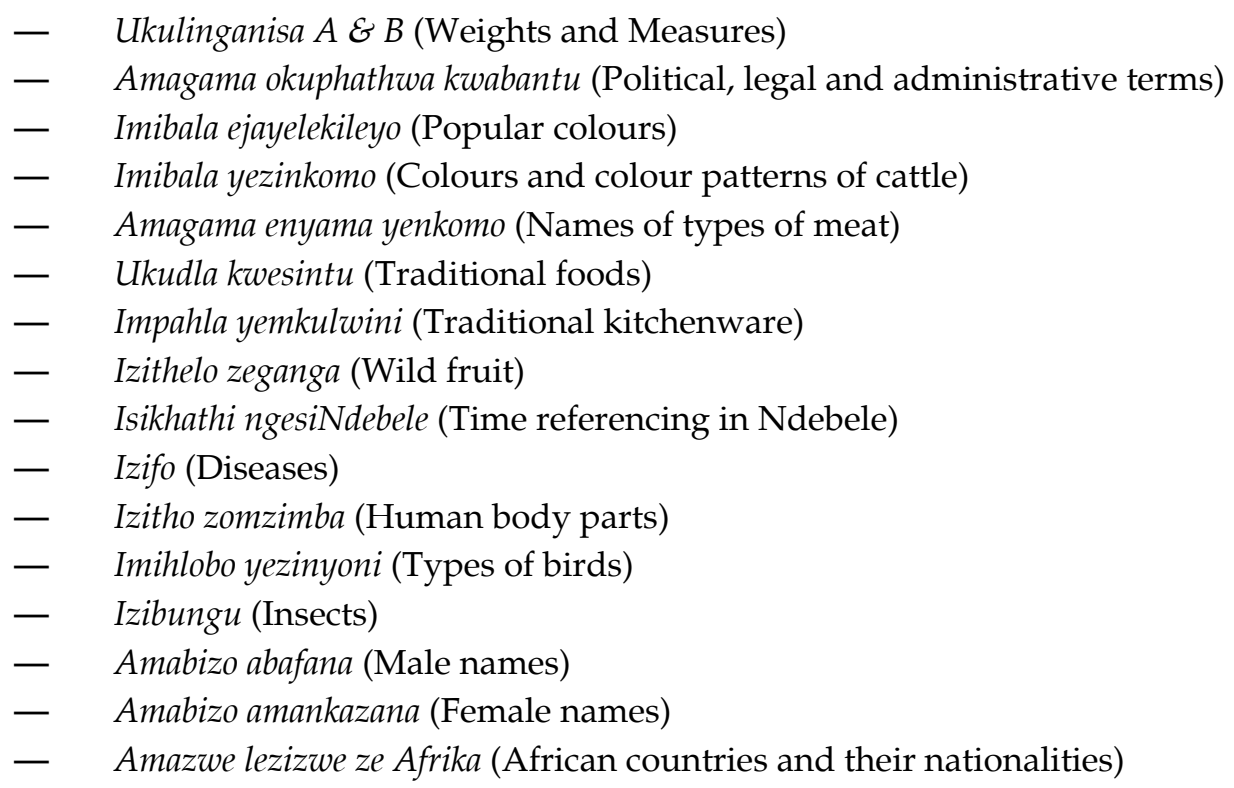

Through these texts, Isichazamazwi SesiNdebele provides information which increases the knowledge of the users pertaining to various phenomena. While the dictionary is mainly preoccupied with various aspects of language in the main text, it has gone a step further to include cultural data which secondary school students, who are the primary target users, may find useful in their study of Ndebele and other subjects. These texts illustrate integrated functionadhering outer texts which do not necessarily serve the same functions as those prevailing in the main text. The same situation is found in Duramazwi Guru reChiShona which, in addition to more or less the same type of texts, contains the following back matter texts:

- Zvirungamutauro (Shona proverbs, idioms and pithy sayings)

- Madzishe nemitupo nezvidao zvavo kumatunhu anotaurwa ChiShona (Names, totems and sub-totems of Shona traditional chiefs)

- Mazwi anoshandiswa kutsanangura zvemaumbirwo emutauro nezveuvaranomwe (Linguistic and literary terms)

Proverbs, idioms and pithy sayings are not usually included in general dictionaries mainly because of the word bias which has dominated lexicographic practice and also because of the uncertainties regarding their best location. In Duramazwi Guru reChiShona, they are actually explained in a text which immediately follows the main Aa-Zz section and which is actually regarded as "Chikamu 2" (Section 2) of the main text. It may be difficult to say whether they are 
part of the main text or the back matter. However, it needs not be overemphasised that their inclusion gives the dictionary an advantage over many monolingual dictionaries. They present useful linguistic and cultural information to the dictionary users, especially Shona students and researchers. Another advantage to users is that instead of buying a dictionary without these sayings and another compilation specifically dealing with them, acquiring Duramazwi Guru reChiShona is handier and cheaper.

The text in Duramazwi Guru reChiShona dealing with the names, totems and sub-totems of traditional Shona chiefs and their areas of influence is another outer text which provides cultural knowledge to the users. The text containing the two alphabetical indices of linguistic and literary terms, the first listing Shona terms and their English equivalents while the second performs a reciprocal role, is equally important to students and scholars of Shona linguistics and literature. The inclusion of the latter was well-advised as it came before the compilation of Duramazwi reDudziramutauro neUvaranomwe, a Shona dictionary of linguistic and literary terms. It is clear from the commentary that has been offered in this section that monolingual lexicography in the African languages is clearly progressing in line with metalexicographic scholarship regarding outer texts.

Another monolingual dictionary of an African language that displays an innovative and progressive utilisation of outer texts is Eiwanika ly'Olusoga, the first monolingual dictionary of the Ugandan language Lusoga. In addition to the front and back matter texts, this dictionary contains a middle matter text. Since the front and back matter texts have been discussed with regard to the Zimbabwean dictionaries, attention is given here to the middle matter texts.

The middle matter in Eiwanika ly'Olusoga consists of four main texts which are listed below:

- Ebyafaayo (Encyclopaedic information)

- Ebifunze (Abbreviations)

- Enfaanana Y'olulimi (Grammatical information, referred to as the language portrait in the translated front matter)

- Okufaanana (Illustrations)

The importance of the middle matter texts in Eiwanika ly'Olusoga needs not be over-emphasised, since the value of similar information has been underlined with respect to other dictionaries. They may also be regarded as integrated function-adhering outer texts. It is the innovative strategy the compiler employed in creating the middle matter out of the respective texts that deserves special attention. Unlike the OBSDNSE/PPSLS which is bilingual, the compiler did not have the advantage of accommodating the middle matter between two $\mathrm{A}-\mathrm{Z}$ sections. Yet the venues for the middle matter texts were not chosen randomly within the main text but in a very meticulous way. The encyclopaedic information in the text Ebyafaayo is "given near the entry of (e)byafaayo" (Na- 
birye 2009: 636). Abbreviations in the text Ebifunze are "listed, translated and then explained ... near the entry (e)kifunze" (Nabirye 2009: 636). The text which provides a grammatical outline of Lusoga is introduced near the entry of gulaama (grammar) (Nabirye 2009: 636). Finally, a collection of all the pictures in the middle matter are "placed near the entry (o)ku.faanan.a (to resemble/look alike)" (Nabirye 2009: 636). Careful observation will reveal a conceptual link between the contents and/or the title of each middle matter text and the macrostructural entry in whose proximity it is placed. This means that, for example, after looking up the meaning of the word ebyafaayo, the user can then access the 'ebyafaayo' about the Basoga people as from the next page. Thus, in addition to the standardisation of the language, the dictionary employs an outer text to impart encyclopaedic, historical and cultural information to the user in a very friendly way. In the case of Ebyafaayo and Enfaanana Y'olulimi, which have sections and subsections, their tables of contents make the data they contain easily accessible.

Finally, another innovation of the Lusoga dictionary as far as outer texts are concerned is the inclusion of an English translation of the front matter as a back matter text, "Appendix 2". Given that Lusoga is categorised as one of the less documented languages (Nabirye 2009: 178), the translated front matter may be useful to those dictionary users who may have problems understanding any part of the front matter. This is possible with respect to the grammatical terms and the metalanguage which the user may encounter for the first time in the dictionary.

\subsection{LSP dictionaries and their outer texts}

Another dictionary genre that has emerged in the African languages is the specialised dictionary. The main motivation for the production of LSP dictionaries in the African languages revolves around terminology development, which is will hopefully promote the languages so that they may play a more advanced role in education and other specialised domains. Four such dictionaries, namely Duramazwi reUrapi neUtano (Shona dictionary of biomedical terms), Duramazwi reMimhanzi (Shona dictionary of music terms), Isichazamazwi SezoMculo (Ndebele dictionary of music terms) and Duramazwi reDudziramutauro neUvaranomwe (Shona dictionary of linguistic and literary terms), have been produced in Zimbabwe since 2004. The need for this type of dictionary is also recognised in South Africa, with the Multilingual Mathematics Dictionary (for Grade R to 6) and Isichazi-magama seziBalo Sezikolo (Xhosa mathematics dictionary for schools) being some notable publications. These dictionaries also display a frame structure just like the other types of dictionaries, but, compared to them, more importance is attached to certain subtexts as part of their outer texts. These include lists of subject field experts, bibliographies and illustrations. 
All the dictionaries mentioned in the previous paragraph contain, in their front matter, lists of subject field experts who participated in the respective dictionary projects. Although all the general dictionaries discussed in this article contain such text segments, the motivation and net effect are quite different. Since most dictionary compilers are linguists themselves, general dictionaries will be found in which the only consulted experts are computer specialists for the creation and management of the dictionary databases. However, the production of LSP dictionaries requires the input of subject field experts. For example, while the lexicographers at ALRI could independently produce the Shona linguistic and literary terms as they are schooled in linguistics and literature, the consultation of relevant subject experts was a prerequisite in the compilation of Duramazwi reUrapi neUtano, Duramazwi reMimhanzi and Isichazamazwi SezoMculo on subject-specific matters. Accordingly, the respective subject field experts are included in the front matter text segments listing the editorial staff members and the project participants. This is also notable in the Multilingual Mathematics Dictionary and Isichazi-magama seziBalo Sezikolo. In the former, acknowledgements constitute the longest front matter text because collaborators including mathematics specialists and translators from English into the other ten official languages are listed. In the latter, the imprint mentions the individuals who provided mathematical expertise as editors in the dictionary project. Clearly, the motivation behind the listing of subject specialists in the front matter of LSP dictionaries is to authenticate the dictionaries whose conceptual quality may be questioned or even compromised if lexicographers work on their own.

Another notably important outer text in LSP dictionaries produced at ALRI is the bibliography which lists the texts, dictionaries and other specialised publications used by lexicographers as part of their dictionary basis. This needs to be seen as more than an academic or ethical procedure. The bibliography may provide the user with other possible references for further consultation on a specific topic.

Whereas LSP dictionaries just like general purpose dictionaries contain back matter comprising texts that provide cultural or specialised information such as tables of weights and measures, the back matter texts in the LSP African language dictionaries tend to be subject specific. For example, the conversion tables, multiplication tables, different calendar months (according to Moslem, Indian and Jewish traditions), mathematical formulae and shapes, among other data in the back matter of Isichazi-magama seziBalo Sezikolo are all relevant for mathematical and numeral literacy in the context of multicultural South Africa. The same applies to illustrations in the back matter of all LSP dictionaries produced by ALRI. For example, in Isichazamazwi SezoMculo, the back matter text "Izingoma ezikhethiweyo" (Selected songs) which also contains Zimbabwe's national anthem, is meant to assist the user in learning how to use the music notation symbols in which these songs are presented. Subject specificity may also be observed regarding the back matter texts in Duramazwi 
reDudziramutauro neUvaranomwe which are specifically included to promote the development of Shona linguistic and literary terminology and scholarship. On this account, most back matter texts in the LSP dictionaries are integrated function adhering as they advance the functions which prevail in the main texts.

\section{Conclusion}

Dictionary structures are some of the elements whose understanding and utilisation reflects the progress that lexicography as a discipline has made. On this account and specifically through the planning and utilisation of outer texts, practising lexicographers in the African languages have not only embraced but also contributed to such progress. It has been shown in this article that outer texts are employed to facilitate data distribution and the realisation of lexicographic functions either prevailing in the main text or not. The focus of the article has therefore been limited to quantitative and qualitative evaluation, the former praising the presence of outer texts and the latter considering the data in them. There are other relevant aspects regarding the utilisation of outer texts such as the reinforcement of the network systems between the various outer texts and the main text, as well as the consistency which may increase the efficacy of the entire dictionary. These were not dealt with here, although it suffices to mention that improvement is required in this regard. The dictionaries studied in this article are those which demonstrate the progress made in the utilisation of outer texts. Far too many dictionaries are still lacking in this regard and those referred to here may be considered as examples of good lexicographic practice in the African languages.

\section{References}

\section{Dictionaries / Encyclopaedias}

Chimhundu, H. (Ed.). 1996. Duramazwi reChiShona. Harare: College Press.

Chimhundu, H. et al. (Eds.). 2001. Duramazwi Guru reChiShona. Harare: College Press.

Chimhundu, H. and Chabata, E. (Eds.). 2006. Duramazwi reDudziramutauro neUvaranomwe. Gweru: Mambo Press.

De Schryver, G.-M. et al. (Eds.). 2007. Oxford Bilingual School Dictionary: Northern Sotho and English / Pukuntšu ya Polopedi ya Sekolo: Sesotho sa Leboa le Seisimane. Cape Town: Oxford.

Hadebe, S. et al. (Eds.). 2001. Isichazamazwi SesiNdebele. Harare: College Press.

Mheta, G. (Ed.). 2005. Duramazwi reMimhanzi. Gweru: Mambo Press.

Mpofu, N. et al. (Eds.). 2003. Duramazwi reUrapi neUtano. Gweru: Mambo Press.

Nabirye, M. (Ed.). 2009. Eiwanika ly'Olusoga. Kampala: Menha Publishers.

National Language Services. Multilingual Mathematics Dictionary: For Grade $R$ to 6. Pretoria: Department of Arts and Culture.

Nkomo, D. and N. Moyo (Eds.). 2006. Isichazamazwi SezoMculo. Gweru: Mambo Press. 
Wababa, Z., K. Welman and K. Press (Eds.). 2010. Isichazi-magama seziBalo Sezikolo. Cape Town: Cambridge University Press.

Weale, M.E. 1903. Matabele and Malaka Vocabulary: Intended for the Use of Prospectors and Farmers in Mashonaland. Cape Town: Murray and St. Leger.

\section{Other literature}

Awak, M.K. 1990. Historical Background, with Special Reference to Western Africa. Hartmann, R.R.K. (Ed.). 1990: 8-18.

Bergenholtz, H. and S. Tarp. 2003. Two Opposing Theories: On H.E. Wiegand's Recent Discovery of Lexicographic Functions. Hermes, Journal of Linguistics 31: 171-196.

Busane, M. Lexicography in Central Africa: The User-Perspective, with Special Reference to Zaire. Hartmann, R.R.K. (Ed.). 1990: 19-35.

Chabata, E. 2007. The African Languages Research Institute: A Milestone in the Development of African Languages. Lexikos 17: 278-291.

Chabata, E. 2008. Language Development: Progress and Challenges in a Multilingual Zimbabwe. Southern African Linguistics and Applied Language Studies 26 (1): 13-26.

Chimhundu, H. 2005. Lexicography and Language Raising: Dictionaries in Zimbabwean Languages. Public lecture presented as part of the Golden Jubilee Celebrations of the University of Zimbabwe, Harare, 13 April 2005.

Gouws, R.H. 1996. A Sequence for Meeting Lexicographic Needs. Lexicography as a Financial Asset in Multilingual South Africa: 97-110. Pretoria: Department of Arts, Culture, Science and Technology.

Gouws, R.H. 2001. Lexicographic Training: Approaches and Topics. Emejulu, J.D. (Ed.). 2001. Éléments de lexicographie gabonaise. Tome I: 58-94. New York: Jimacs-Hillman.

Gouws, R.H. 2002. Using a Frame Structure to Accommodate Cultural Data. Emejulu, J.D. (Ed.). 2002. Éléments de lexicographie gabonaise. Tome II: 54-69. New York: Jimacs-Hillman.

Gouws, R.H. 2004. Outer Texts in Bilingual Dictionaries. Lexikos 14: 67-88.

Gouws, R.H. 2005. Lexicography in Africa. Brown, K. (Ed.). 2005. Encyclopedia of Language and Linguistics: 95-101. Second Edition. Oxford: Elsevier.

Gouws, R.H. 2007. A Transtextual Approach to Lexicographic Functions. Lexikos 17: 77-87.

Gouws, R.H. and D.J. Prinsloo. 2005. Principles and Practice of South African Lexicography. Stellenbosch: SUN PReSS.

Hadebe, S. 2006. The Standardisation of the Ndebele Language through Dictionary-Making. Harare/ Oslo: The ALLEX Project.

Hartmann, R.R.K. (Ed.). 1990. Lexicography in Africa. Progress Reports from the Dictionary Research Centre Workshop at Exeter, 24-25 March 1989. Exeter Linguistic Studies 15. Exeter: University of Exeter Press.

Hausmann, F.J. et al. (Eds.). 1989-1991. Wörterbücher. Ein internationales Handbuch zur Lexikographie/Dictionaries. An International Encyclopedia of Lexicography/Dictionnaires. Encyclopédie internationale de lexicographie. Handbücher zur Sprach- und Kommunikationswissenschaft 5.1-5.3. Berlin/New York: W. de Gruyter.

Nielsen, S. 2009. The Evaluation of Outside Matter in Dictionary Reviews. Lexikos 19: 207-224. 
Nkomo, D. 2008. Towards a Theoretical Model for LSP Lexicography in Ndebele with Special Reference to a Ndebele Dictionary of Linguistic and Literary Terms. Unpublished M.Phil. Thesis. Stellenbosch: Stellenbosch University.

Svensén, B. 2009. A Handbook of Lexicography: The Theory and Practice of Dictionary-Making. Cambridge: Cambridge University Press.

Tarp, S. 2000. Theoretical Challenges to Practical Specialised Lexicography. Lexikos 10: 189-208.

Tarp, S. 2008. Lexicography in the Borderland between Knowledge and Non-knowledge. General Lexicographical Theory with Particular Focus on Learner's Lexicography. Lexicographica. Series Maior 134. Tübingen: Max Niemeyer.

Wiegand, H.E. 1984. On the Structure and Contents of a General Theory of Lexicography. Hartmann, R.R.K. (Ed.). 1984. LEXeter '83 Proceedings. Papers from the International Conference on Lexicography at Exeter, 9-12 September 1983: 13-30. Lexicographica. Series Maior 1. Tübingen: Max Niemeyer.

Wiegand, H.E. and Hausmann, F.J. 1989. Component Parts and Structures of General Monolingual Dictionaries: A Survey. Hausmann, F.J. et al. (Eds.). 1989-1991: 328-360.

Zgusta, L. 1991. Probable Future Developments in Lexicography. Hausmann, F.J. et al. (Eds.). 19891991: 3157-3167. 